\title{
Comparative analysis of combustion engine and hybrid propulsion unit in aviation application in terms of emission of harmful compounds in the exhausts emitted to the atmosphere
}

Comparative analysis of combustion and hybrid propulsion unit in aviation application in terms of emission of harmful compounds in the exhausts emitted to the atmosphere. For the propulsion of the AOS 71 motor glider, two types of propulsion were planned as development versions. The first analysed propulsion is based on a combustion engine, but of the Wankel type (LCR 814 engine with the power of $55 \mathrm{~kW}$ ). The second designed propulsion is an hybrid based on a LCR 407 combustion engine with a power of $28 \mathrm{~kW}$, which is connected in series with an electric generator propelling the engine (Emrax 228 engine), total power of the propulsion is $55 \mathrm{~kW}$. The comparison of emissions of harmful compounds emitted to the atmosphere generated by the combustion and hybrid power unit intended for assembly in the AOS 71 motor glider, assuming various loads and methods of hybrid propulsion control, was made. The tests were conducted in laboratory conditions. Several different programs were designed to simulate different energy management methods in a hybrid system, depending on the predicted mission and load of the motor glider. On the basis of laboratory tests, exhaust emission was determined from both propulsions as a function of rotational speed and load. Then, based on the assumed flight trajectory and collected test data, the emission for both propulsions variants was determined. The values of emission parameters were compared and the results were presented in diagrams and discussed in the conclusions

Key words: hybrid, combustion engines, motor glider, rotary engine, Wankel engine, hybrid propulsion, emission, exhaust gases

\section{Introduction}

The environmental aspects of aircraft operation are discussed more and more frequently [7, 10, 12]. It has become important to reduce fuel consumption and emissions of harmful and toxic compounds present in the exhausts of aircraft engines [10]. The impact of aviation on the environment refers not only to commercial communication aviation, but also to small, short-distance or amateur aviation using aircraft equipped with reciprocating engines. Attempts to use hybrid propulsion are made, following the solutions used in the automotive industry, which are characterized by lower emission of pollutants and fuel consumption compared to traditional propulsion systems (especially in the range of work under load - acceleration) [7, 12]. A similar analysis relating to the flight of the aircraft on a known flight path can be performed for an aircraft.

The paper presents a comparative analysis of conceptual propulsions intended for use in the AOS 71 motor glider. The "pure" combustion propulsion system based on a rotary piston engine (Wankel) and also a hybrid one with an electric generator (so-called range extender) were investigated.

\section{Research object}

For the analysis there was taken the airframe of the AOS-71 electric glider (Fig. 1), built as part of the cooperation between the Department of Aircraft and Aircraft Engines of the Rzeszow University of Technology and the Faculty of Power and Aeronautical Engineering of the Warsaw University of Technology.

Table 1 shows the basic data of the airframe, while Figs 2 and 3 present the values of power required for the flight for this airframe and the efficiency of its propeller depending on the flight speed.

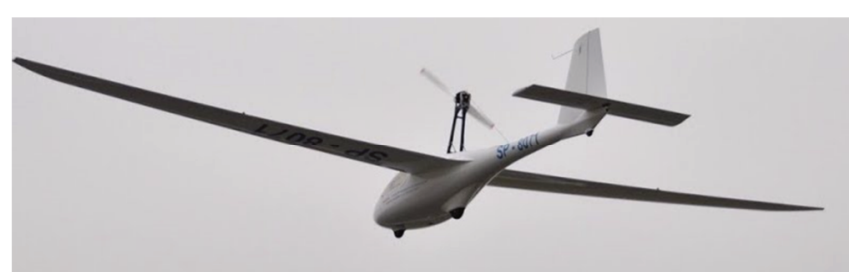

Fig. 1. The AOS 71 motor glider

Table 1. Basic data of the AOS 71 motor glider) $[8,9]$

\begin{tabular}{|l|c|c|}
\hline Wing area & $\mathrm{S}\left[\mathrm{m}^{2}\right]$ & 15.8 \\
\hline Wing span & $\mathrm{R}[\mathrm{m}]$ & 16.4 \\
\hline Aspect ratio & $\Lambda$ & 17 \\
\hline $\begin{array}{l}\text { Maximum take-off } \\
\text { mass }\end{array}$ & $\mathrm{M}_{\max }[\mathrm{kg}]$ & 660 \\
\hline $\begin{array}{l}\text { Minimum motor } \\
\text { glider mass }\end{array}$ & $\mathrm{M}_{\min }[\mathrm{kg}]$ & 500 \\
\hline
\end{tabular}

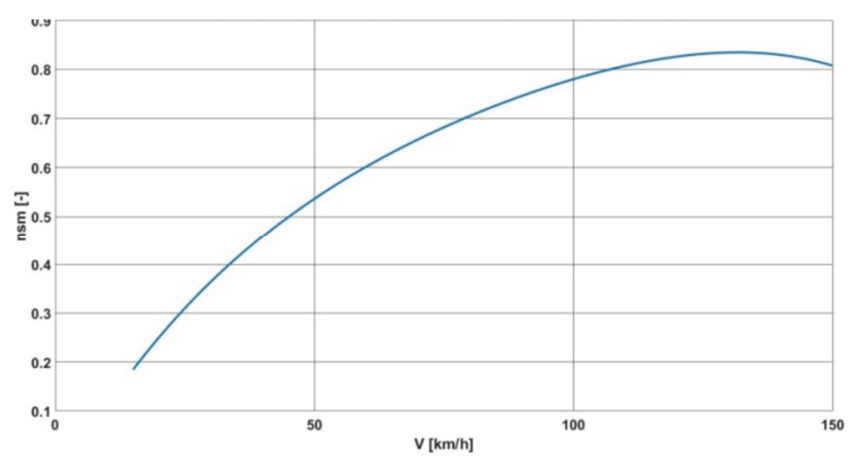

Fig. 2. Efficiency of propeller in the function of flight speed - for the AOS 71 motor glider $[6,7]$ 


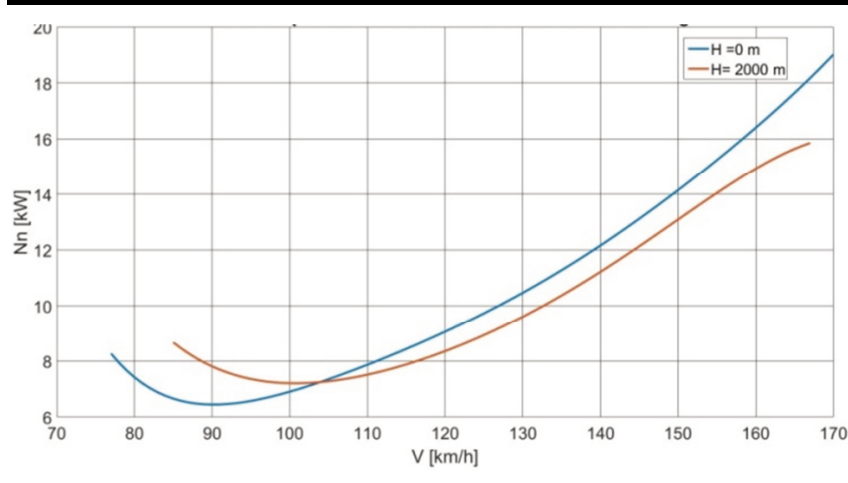

Fig. 3. Power required for flight in the function of flight speed - for the AOS 71 motor glider; $M_{\max }=660 \mathrm{~kg}[6,7]$

For the combustion propulsion, the propeller was driven by a rotary piston $814 \mathrm{TGi}$. The second propulsion was a hybrid unit, where the batteries located on-board the motor glider deck were supported by an electric generator driven by a 407 TGi combustion engine. Technical data of power units is shown in Table 2.

Fig. 4 and 5 show the indicated rotational characteristics for both engines.

Table 3. Technical data of power unit $[8,9,13]$

\begin{tabular}{|l|c|c|c|}
\hline Engine & & $407 \mathrm{TGi}$ & $814 \mathrm{TGi}$ \\
\hline $\begin{array}{l}\text { Maximum engine } \\
\text { power }\end{array}$ & $\mathrm{N}_{\max }[\mathrm{kW}]$ & 31.5 & 55 \\
\hline Maximum torque & $\mathrm{M}_{\max }[\mathrm{Nm}]$ & 51 & 9 \\
\hline Engine mass & $\mathrm{m}_{\mathrm{s}}[\mathrm{kg}]$ & 20 & 35 \\
\hline $\begin{array}{l}\text { Specific fuel con- } \\
\text { sumption }\end{array}$ & $\begin{array}{c}\mathrm{SFC}_{\min } \\
{[\mathrm{kg} / \mathrm{kWh}]}\end{array}$ & 0.3 & 0.3 \\
\hline Battery & - & Li-Pol & - \\
\hline Capacity & $\mathrm{C}[\mathrm{Ah}]$ & 16 & - \\
\hline Voltage & $\mathrm{U}_{\text {bat }}[\mathrm{V}]$ & 355 & - \\
\hline Battery mass & $\mathrm{m}_{\text {bat }}[\mathrm{kg}]$ & 50 & - \\
\hline
\end{tabular}

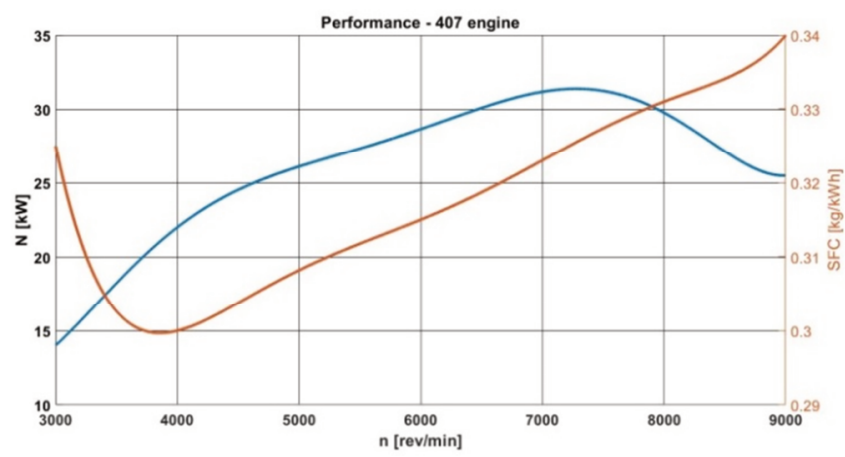

Fig. 4. Rotational characteristics of the 407 engine

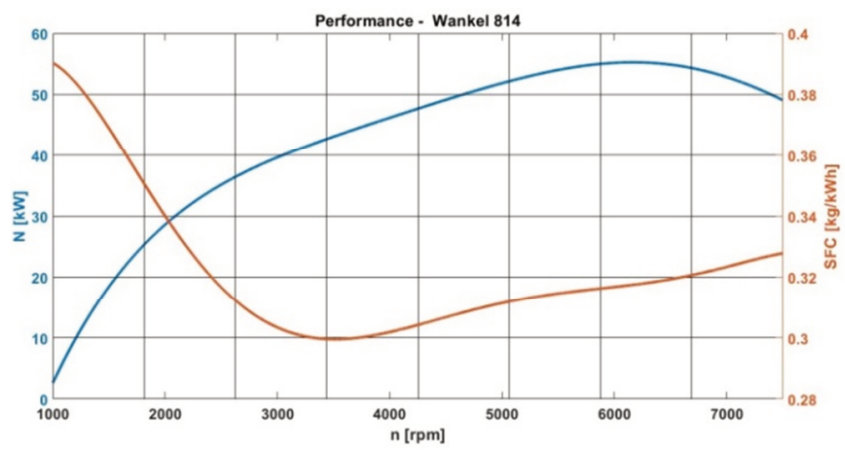

Fig. 5. Rotational characteristics of the 814 engine

\section{Research selection of flight mission parameters for analysis}

For the parameters of both propulsions were selected for the analysis in such a way that approximately 3 hours of flight duration and $300 \mathrm{~km}$ of range is ensured. It was assumed that these parameters will be obtained when the energy resources accumulated on-board the motor glider are completely exhausted. Based on the aerodynamic characteristics of the airframe (Figs 2 and 3) the power required for the flight for a horizontal speed of $100 \mathrm{~km} / \mathrm{h}$ and a take-off mass of $660 \mathrm{~kg}$ was selected. For these parameters, the power required for flight $(7 \mathrm{~kW})$ of was determined. Based on the characteristics of the course of specific fuel consumption of the engines, the parameters of their operation were selected to ensure the desired range. As a result of the analysis conducted, the fuel reserve for reaching the range was determined - it was $10 \mathrm{~kg}$ for the combustion variant in and $7 \mathrm{~kg}$ for the hybrid one. The emission of toxic compounds on a given route depends on the amount of fuel burned and the range of operation of internal combustion engines during the flight. In the case of the 814 TGi engine, the operating parameters for the cruising conditions were $10 \mathrm{~kW}$ at revolutions similar the idle speed (1500 rpm). However, for the $407 \mathrm{TGi}$ engine, which worked as an electric generator propulsion, it was $22 \mathrm{~kW}$ at the maximum torque value and engine revolutions of $4000 \mathrm{rpm}$. This range was covered at close to the minimum specific fuel consumption. It was assumed that the propulsions work continuously.

\section{Research on emissions of harmful and toxic compounds}

In piston engine exhausts there are emitted such compounds as carbon dioxide, carbon monoxide, nitrogen oxides and unburned hydrocarbons [4, 10, 12]. Emission depends on the engine design, the combustion temperature and the pressure in the cylinder. In the case of Wankel engines, which were taken into account in the analysis, a 1:80 oil-fuel mixture was used for feeding, in accordance with the manufacturer's requirements. The emission of harmful compounds was carried out in an experimental way, using Horiba exhaust gas analyser and the test bench for engines located in the Aviation Engine Laboratory of the Department of Aircraft and Aircraft Engines at Rzeszow Technical University.

Figures 6, 7 and 8 show test stands and devices on which engine exhausts measurements were made.

The measurement was made at the ambient temperature of $12^{\circ} \mathrm{C}$.

The Horiba apparatus indicated the values of $\mathrm{NO}_{\mathrm{x}}$ in $[\mathrm{ppm} / \mathrm{mol}]$ with reference to the control volume, and $\mathrm{CO}$ and $\mathrm{CO}_{2}$ as a percentage $[\% / \mathrm{vol}]$ with reference to the control volume.

Based on the obtained measurement results, using Matlab software, the emission profile of pollutants in engine exhausts $\left(\mathrm{CO}_{2}, \mathrm{CO}, \mathrm{NO}_{\mathrm{x}}\right)$ was determined in the function of rotational speed. The results of the tests are presented in Figures 9, 10 and 11. 


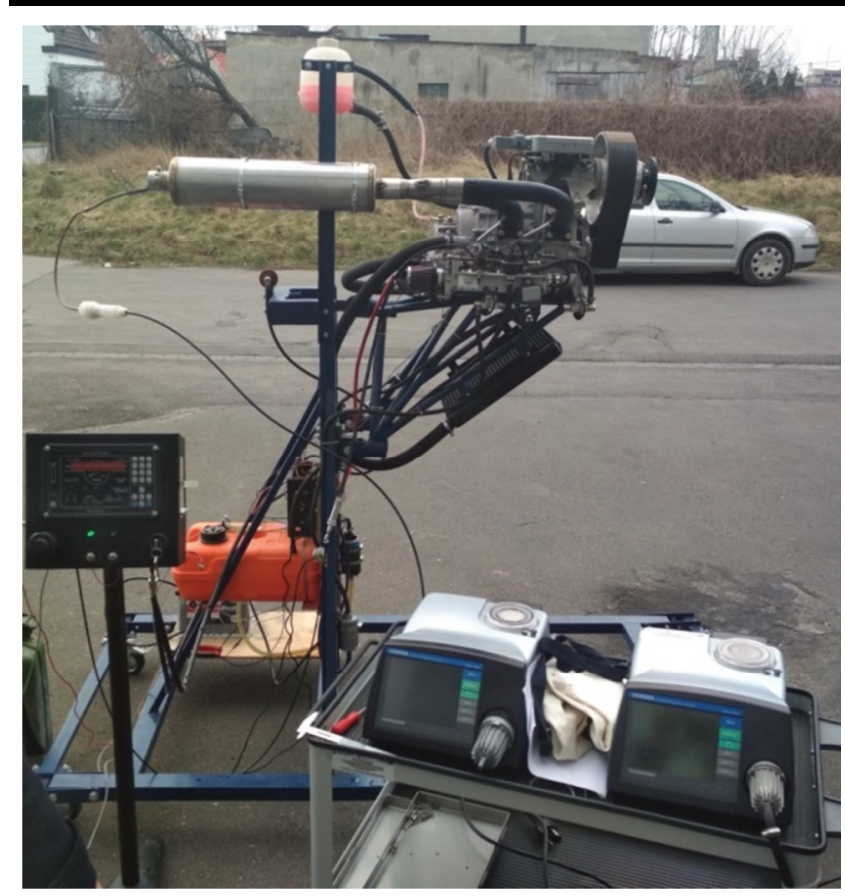

Fig. 6. Test stand - measurement conducted for the 814 TGi engine

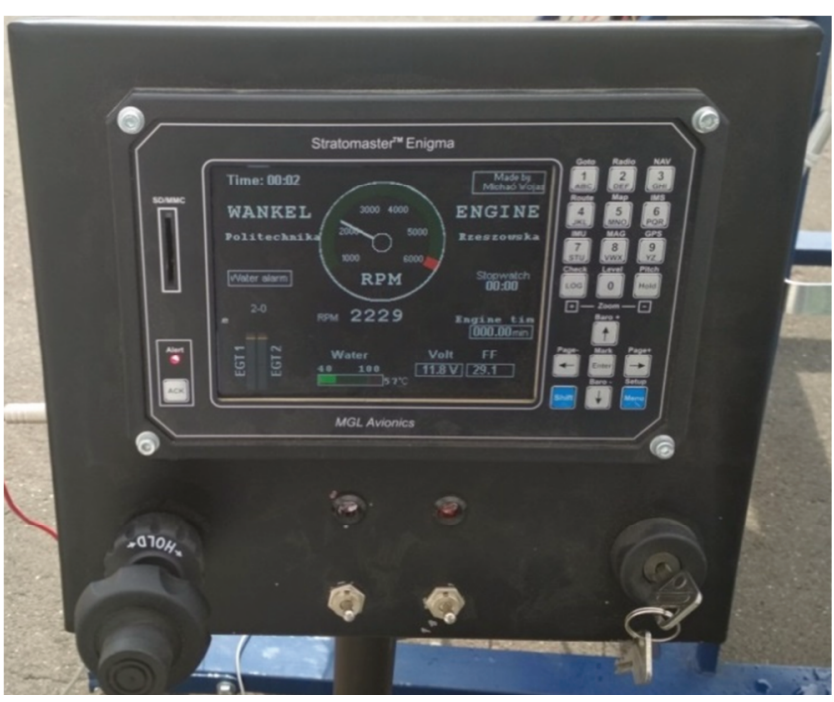

Fig. 7. Test stand - a panel used for reading engine operation parameters

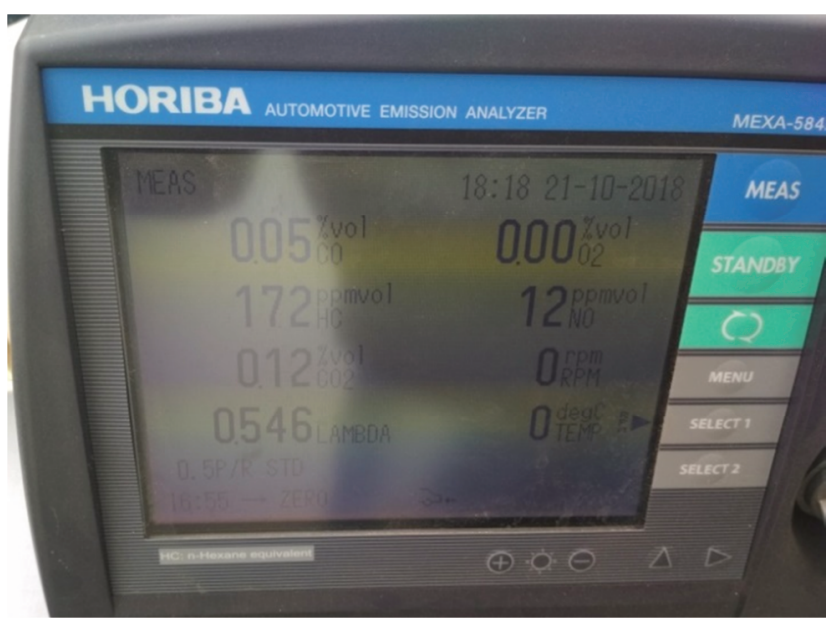

Fig. 8. Test stand - Horiba apparatus display (after switching off the engine)

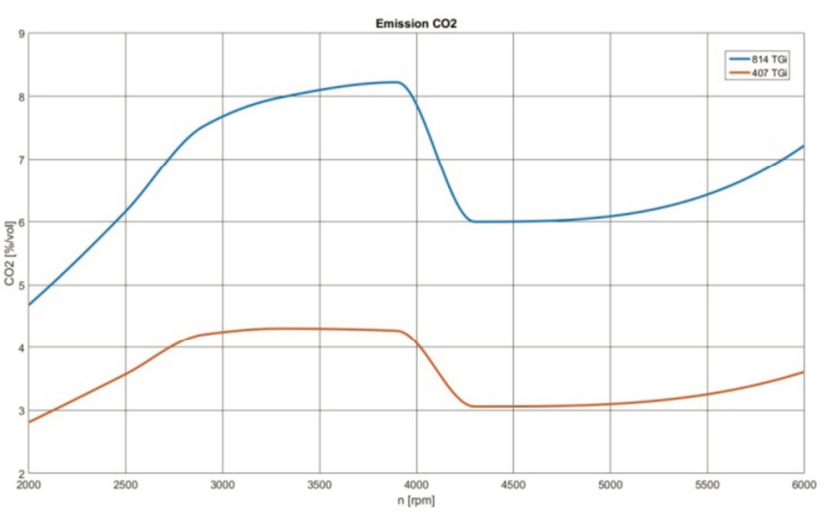

Fig. 9. The $\mathrm{CO}_{2}$ emission profile for internal combustion engines in the function of rotational speed

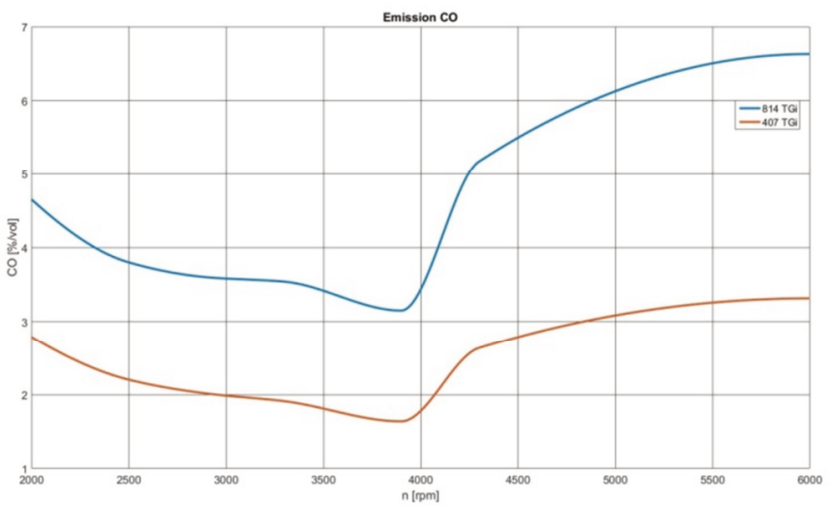

Fig. 10. The $\mathrm{CO}$ emission profile for internal combustion engines in the function of rotational speed

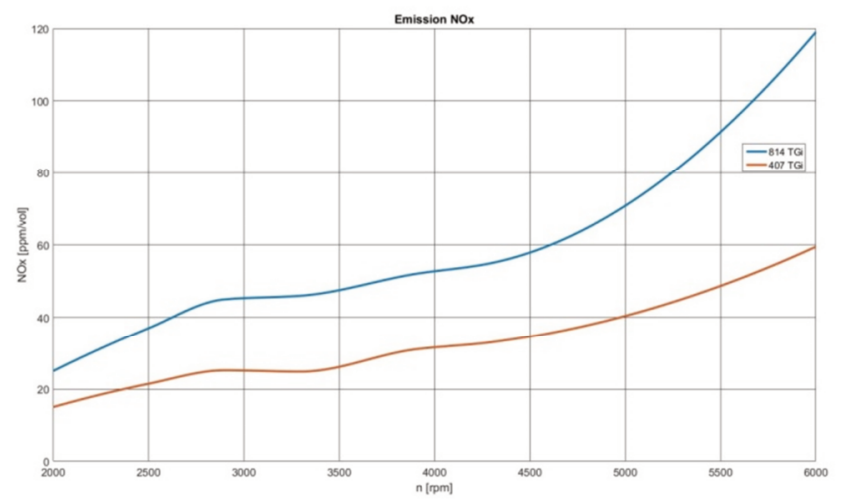

Fig. 11. The $\mathrm{NO}_{\mathrm{x}}$ emission profile for internal combustion engines in the function of rotational speed

The analysis of the harts presented in the Figs 9-11, leads to the following conclusions:

1. The $\mathrm{CO}_{2}$ and $\mathrm{CO}$ emissions were the lowest in the vicinity of the maximum torque obtained by the engines (about $4000 \mathrm{rpm}$ ), which at the same time was a point close to minimum of specific fuel consumption.

2. The $\mathrm{NO}_{\mathrm{x}}$ emission grew continuously in the function of rotational speed, which was associated with the increase in the combustion temperature and the increase in fuel consumption by the engines.

For the assumed mission profile (i.e. start and flight at $600 \mathrm{~m}$, as illustrated in Fig. 12), the emission of particular 
compounds generated on a given route in the control volume was determined, assuming:

- the range until the energy source is depleted - about $300 \mathrm{~km}$,

- the flight duration corresponding to the flight range - 3 hours of flight,

- the horizontal flight speed $\mathrm{V}=100 \mathrm{~km} / \mathrm{h}$, the climb speed $\mathrm{W}=2.3 \mathrm{~m} / \mathrm{s}$,

- the ambient conditions corresponding to the parameters according to the International Standard Atmosphere at a given altitude and the lack of wind.

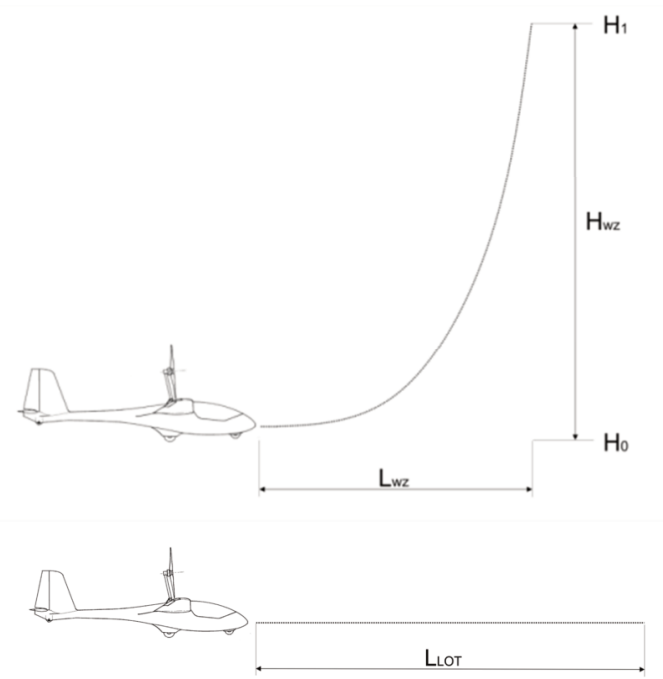

Fig. 12. Flight profile - climb (up) and horizontal flight (down)

\section{The analysis results}

In the first step, the energy accumulated on-board the motor glider was determined for both propulsions variants.

For the hybrid propulsion, the formula for determining accumulated energy takes the form $[1,11]$ :

$$
\mathrm{E}=\mathrm{I} \cdot 3600[\mathrm{~s}] \cdot \mathrm{U}_{\mathrm{bat}}+\eta_{\text {gen }} \cdot\left(\mathrm{N}_{\mathrm{s}} \cdot \mathrm{t}_{\mathrm{s}}\right)
$$

where $t_{s}-$ generator operation time [1]:

$$
\mathrm{t}_{\mathrm{s}}=\frac{\mathrm{m}_{\mathrm{fuel}}}{\mathrm{SFC} \cdot \mathrm{N}_{\mathrm{s}}}
$$

The energy generated by the combustion engine accounted for $70 \%$ of the energy accumulated on-board, the remaining $30 \%$ was accumulated in the battery assembly.

The energy accumulated on-board for the combustion variant is given with the formula [7]:

$$
\mathrm{E}=\mathrm{W}_{\mathrm{D}} \cdot \mathrm{m}_{\text {fuel }}
$$

where: $\mathrm{W}_{\mathrm{D}}$ - fuel calorific value, equal to $42 \mathrm{MJ} / \mathrm{kg}, \mathrm{m}_{\text {fuel }}-$ fuel mass, equal to $10 \mathrm{~kg}$.

Figure 13 shows the energy accumulated on-board.

As mentioned, the energy accumulated on-board for both propulsions was selected in such a way that for the same take-off mass and the range of operation of combustion engines for the flight with the speed of $100 \mathrm{~km} / \mathrm{h}$, they provide the same range and duration of the flight.

As a result of the conducted analysis, the emission of harmful and toxic compounds was determined for a selected flight trajectory. The obtained data is presented in diagrams (Figs 14-17).

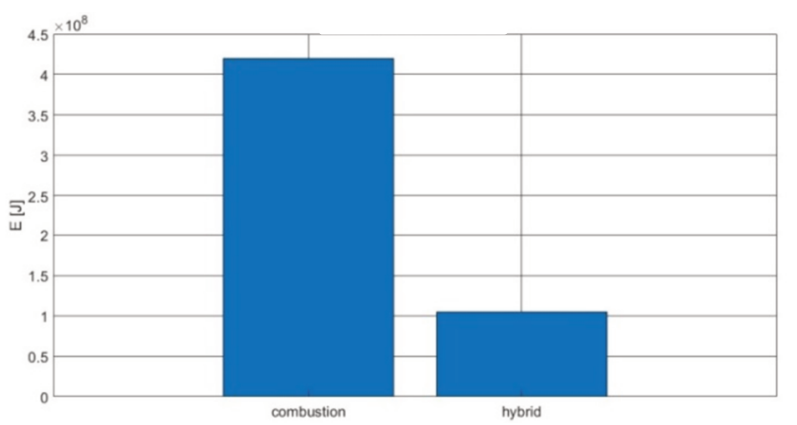

Fig. 13. The energy accumulated on-board

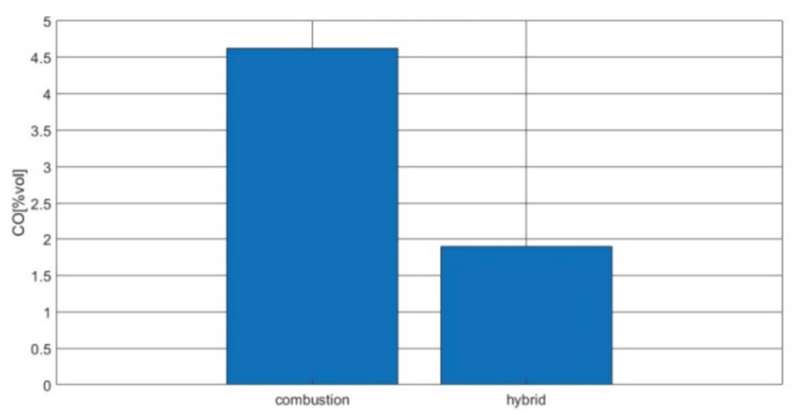

Fig. 14. The $\mathrm{CO}$ emission for propulsion units

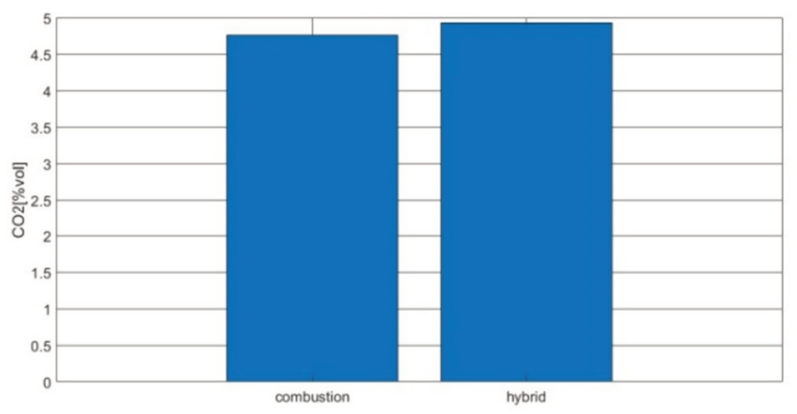

Fig. 15. The $\mathrm{CO}_{2}$ emission for propulsion units

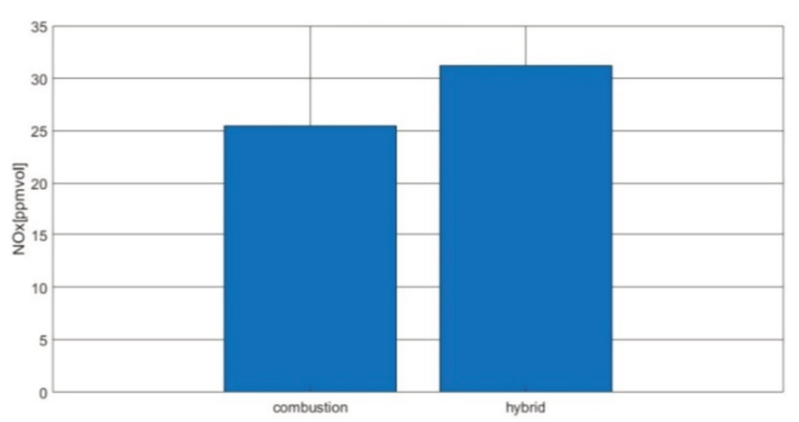

Fig. 16. The $\mathrm{NO}_{\mathrm{x}}$ emission for propulsion units

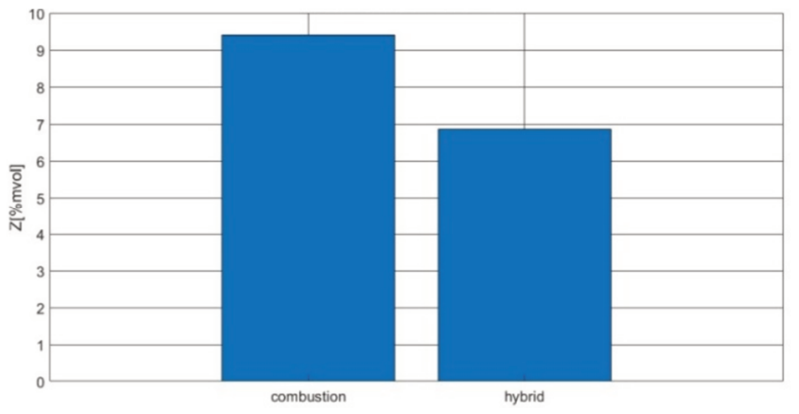

Fig. 17. The total emission for propulsion units 
As can be noticed, the hybrid propulsion was characterized by the $\mathrm{CO}$ emission lower by almost $60 \%$ in comparison to the combustion engine - at the same level of power supplied to the propeller. The $\mathrm{CO}_{2}$ and $\mathrm{NO}_{\mathrm{x}}$ emissions were higher for hybrid propulsion by $3.7 \%$ and $22.5 \%$ respectively. It was related to the range of work of internal combustion engines. The 814 engine worked at small load, which resulted in low combustion temperature and high fuel consumption. This caused a situation favourable to the formation of excessive amounts of $\mathrm{CO}$ as an incomplete combustion product. In the case of the internal combustion engine driving the generator, it operated within its maximum torque, the load was relatively high ( $22 \mathrm{~kW}$ compared to the maximum power of 31.5), which resulted in more favourable exhaustreheat in the combustion chamber (lower emission of $\mathrm{CO}$, higher emission of $\mathrm{CO}_{2}$ ). High $\mathrm{NO}_{\mathrm{x}}$ emission was associated with a higher combustion temperature. The total emission of harmful and toxic compounds for the hybrid propulsion was lower by $27 \%$ compared to the internal combustion engine. It is worth noting that at the same distance and with the same take-off mass, the hybrid system used $7 \mathrm{~kg}$ of fuel in relation to $10 \mathrm{~kg}$ by traditional propulsion.

\section{Conclusion}

The obtained results show that the use of a properly selected and configured hybrid system can bring benefits in the form of a decrease in fuel consumption and total emissions during the flight on a given route. Appropriate matching of the generator operation range to the aerodynamic parameters and mass of the airframe will enable to get even more satisfactory results. Therefore, an interesting research perspective seems to be the optimization of such a propulsion in terms of minimizing fuel consumption while maintaining the same performance parameters of the aircraft (i.e. maintaining the flight duration and range at the same level). However, this requires a systematic approach to the construction of a hybrid propulsion. The tests were conducted on commercial engines. The optimization of the above tested conditions would be possible when the entire propulsion (combustion engine and electric) was designing as systems dedicated for this type of aircraft and the task performed. With unitary production of motor gliders this is uneconomical though. Therefore, attention should be paid to optimization of the selection of individual components in order to minimize emissions while maintaining energy requirements.

\section{Acknowledgements}

The research presented in this paper was financed as project PBS3/A6/24/2015 "AOS-H2" of the Applied Research Programme (PBS) of the National Centre for Research and Development (NCBIR), Poland, in the years 2015-19.

\section{Bibliography}

[1] ANDERSON, J. Introduction to flight. McGraw Hill Book Company, San Francisco 2003.

[2] BOJOI, R., BOGGERO, H. et al. Multiphase drives for hybrid-electric propulsion in light aircrafts: a viable solution. 2018 International Symposium on Power Electronics, Electrical Drives, Automation and Motion (SPEEDAM). DOI: 10.1109/SPEEDAM.2018.8445241

[3] GEISS, I., VOIT-NITSCHMANN, R. Sizing of fuel-based energy systems for electric aircrafts. Proceedings of the Institution of Mechanical Engineers Part G-Journal of Aerospace Engineering. 2017, 231. DOI: 10.1177/0954410017721254

[4] FAHIM, M. An overview of double-bar single-whee rotary combustion engine. Advances in Mechanical Engineering. 2019, 11(2), 1-13. DOI: 10.1177/1687814019828074

[5] HENDERSON, R.P., MARTINS, J.R.R.A., PEREZ, R.E. Aircraft conceptual design for optimal environmental performance. The Aeronautical Journal. 2012, 116(1175), 1-22.

[6] JAKUBOWSKI, R., ORKISZ, M. A review of selected alternative propulsion systems for UAV applications. Zeszyty Naukowe/Wyższa Szkoła Oficerska Sit Powietrznych Dęblin. 2015, 231. DOI: 10.1177/0954410017721254
[7] KOTLARZ, W. Turbinowe zespoły napędowe źródłem skażeń powietrza na lotniskach wojskowych. Wyższa Szkoła Oficerska Sit Powietrznych. Dęblin 2003.

[8] MARIANOWSKI, J., FRACZEK, W., CZARNOCKI, F. Założenia podstawowe dla projektu motoszybowca AOSH2. (not publish)

[9] MARIANOWSKI, J., TOMASIEWICZ, J., CZARNOCKI, F. Analiza masowa motoszybowca AOS-H2. (not publish)

[10] PAWLAK, M. Metoda modelowania emisji szkodliwych i toksycznych składników spalin turbinowych silników odrzutowych samolotów pasażerskich w warunkach przelotowych. Wyd. Uniwersytetu Morskiego. Gdynia 2019.

[11] ROSKAM, J. Airplane aerodynamics and performance. DARcorporation. Kansas 2016.

[12] SINGH, V. Perceptions of emission reduction potential in air transport: a structural equation modeling approach, Environment Systems and Decisions. 2016, 36(4), 377-403.

[13] WANKEL AG, Wankel engine manual

[14] www.emrax.com
Prof. Marek Orkisz, DSc., DEng. - Faculty of Mechanical Engineering and Aeronautics, Rzeszow University of Technology. e-mail:mareko@prz.edu.pl

Michał Kuźniar, MEng. - Faculty of Mechanical Engineering and Aeronautics, Rzeszow University of Technology.

e-mail:mkuzniar@prz.edu.pl
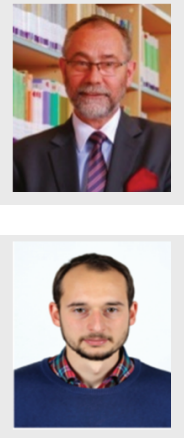

Piotr Wygonik, DEng. - Faculty of Mechanical Engineering and Aeronautics, Rzeszow University of Technology. e-mail:piowyg@prz.edu.pl

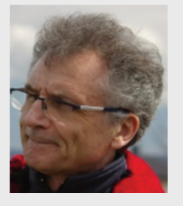

Maciej Kalwara, MEng. - Faculty of Mechanical Engineering and Aeronautics, Rzeszow University of Technology.

e-mail:kalmac@prz.edu.pl 